\title{
Isoprenoid emission response to changing light conditions of English oak, European beech and Norway spruce
}

\author{
Ylva van Meeningen ${ }^{1}$, Guy Schurgers ${ }^{2}$, Riikka Rinnan $^{3}$, and Thomas Holst ${ }^{1,3}$ \\ ${ }^{1}$ Department of Physical Geography and Ecosystem Science, Lund University, Sölvegatan 12, 22362 Lund, Sweden \\ ${ }^{2}$ Department of Geosciences and Natural Resource Management, University of Copenhagen, Øster Voldgade 10, \\ 1350 Copenhagen K, Denmark \\ ${ }^{3}$ Terrestrial Ecology Section, Department of Biology, University of Copenhagen, Universitetsparken 15, \\ 2100 Copenhagen E, Denmark \\ Correspondence to: Ylva van Meeningen (ylva.van_meeningen@nateko.lu.se)
}

Received: 5 December 2016 - Discussion started: 2 January 2017

Revised: 13 July 2017 - Accepted: 23 August 2017 - Published: 15 September 2017

\begin{abstract}
Light is an important environmental factor controlling biogenic volatile organic compound (BVOC) emissions, but in natural conditions its impact is hard to separate from other influential factors such as temperature. We studied the light response of foliar BVOC emissions, photosynthesis and stomatal conductance on three common European tree species, namely English oak (Quercus robur), European beech (Fagus sylvatica) and two provenances of Norway spruce (Picea abies) in Taastrup, Denmark. Leaf scale measurements were performed on the lowest positioned branches of the tree in July 2015. Light intensity was increased in four steps $\left(0,500,1000\right.$ and $\left.1500 \mu \mathrm{mol} \mathrm{m}^{-2} \mathrm{~s}^{-1}\right)$, whilst other chamber conditions such as temperature, humidity and $\mathrm{CO}_{2}$ levels were fixed.

Whereas the emission rate differed between individuals of the same species, the relative contributions of compounds to the total isoprenoid emission remained similar. Whilst some compounds were species specific, the compounds $\alpha$-pinene, camphene, 3-carene, limonene and eucalyptol were emitted by all of the measured tree species. Some compounds, like isoprene and sabinene, showed an increasing emission response with increasing light intensity, whereas other compounds, like camphene, had no significant emission response to light for most of the measured trees. English oak and European beech showed high light-dependent emission fractions from isoprene and sabinene, but other emitted compounds were light independent. For the two provenances of Norway spruce, the compounds $\alpha$-pinene, 3 -carene and eucalyptol showed high light-dependent fractions for many of the mea-
\end{abstract}

sured trees. This study highlights differences between compound emissions in their response to a change in light and a possible light independence for certain compounds, which might be valid for a wider range of tree species. This information could be of importance when improving emission models and to further emphasize the discussion regarding light or temperature dependencies for individual compounds across species.

\section{Introduction}

Biogenic volatile organic compounds (BVOCs) are produced in both marine and terrestrial environments, playing important roles in both plant survival and the reactive chemistry of the atmosphere (Guenther et al., 1995; Goldstein and Galbally, 2007). Isoprenoids, such as isoprene (a $\mathrm{C}_{5}$ unit), monoterpenes (MTs, consisting of two $\mathrm{C}_{5}$ units) and sesquiterpenes (SQTs, consisting of three $\mathrm{C}_{5}$ units), contribute with approximately $68 \%$ of the total global BVOC emissions (Guenther et al., 2012). They are some of the most important BVOC groups due to their high volatility and involvement in several atmospheric reactions (Atkinson and Arey, 2003; Goldstein and Galbally, 2007; Guenther et al., 2012). The degradation of BVOCs in the air influences atmospheric processes such as production and destruction of ozone (Atkinson, 2000; Peñuelas and Staudt, 2010), but it also influences the growth of secondary organic aerosols (SOA) (Claeys et al., 2004; Ehn et al., 2014). SOA parti- 
cles are known to scatter incoming solar radiation and to act as cloud condensation nuclei, which in turn have an effect on the incoming and outgoing radiation (Laothawornkitkul et al., 2009, and references therein; Paasonen et al., 2013). In general, SOA yields are expected to be higher for compounds with internal double bonds, such as $\alpha$-pinene, 3carene, limonene and terpinolene. However, some acyclic compounds, such as myrcene, have also been observed to produce high SOA yields (Lee et al., 2006, and references therein).

The production and release of BVOCs are sensitive to physical constraints such as light and temperature (Staudt and Bertin, 1998; Niinemets et al., 2004; Dudareva et al., 2006). Temperature controls the synthesis of isoprenoids and the diffusion rate of compounds (Niinemets et al., 2004, and references therein). The light availability determines the amount of isoprenoid precursors produced by photosynthesis and the available amount of ATP and NADPH, which are used in the $\mathrm{CO}_{2}$ fixation and assimilation reactions that provide new isoprenoids (Niinemets et al., 2004, and references therein; Lichtenthaler, 2007). However, the emission rates can also be affected by physiochemical constraints, such as stomatal conductance $\left(G_{\mathrm{S}}\right)$. $G_{\mathrm{S}}$ can control VOC emissions temporarily in a non-steady state, when the intercellular volatile partial pressure is different from the equilibrium pressure (Niinemets and Reichstein, 2003). In a steady state, isoprene and MTs are insensitive to stomatal closure because of their high gas-phase to liquid-phase partitioning. Compounds with a large Henry's law constant (H), such as isoprene and MTs, partition to the gas phase, whilst low $\mathrm{H}$ compounds partition to the aqueous phase. When $G_{\mathrm{S}}$ decreases, it elevates the gas-phase partial pressure inside the stomata and increases the gradient between the intercellular air space and atmosphere. This allows the diffusion flux of compounds with a high $\mathrm{H}$ to be maintained independently of stomatal conductance (Niinemets and Reichstein, 2003; Niinemets et al., 2004).

Isoprene is released upon production and therefore shows a strong direct temperature and light dependency (Kesselmeier and Staudt, 1999; Niinemets et al., 2004). The light dependency of MT emissions has, however, been more debated. In earlier studies regarding MT emissions, a lack of light response led to the assumption that MTs were only temperature dependent (Tingey et al., 1980). Emissions of MTs were assumed to originate from internal storage structures in plants, such as resin ducts, oil glands or glandular hairs and trichomes (Fuentes et al., 1996; Kesselmeier and Staudt, 1999). The evaporation from these structures is controlled by the vapour pressure of the MTs, which in turn is affected by the air temperature and concentration of MTs within these structures (Lerdau et al., 1997; Ghirardo et al., 2010; Taipale et al., 2011). However, more recent studies have suggested that both de novo and storage pool emissions can occur simultaneously. Amongst MT-emitting broadleaved trees, such as Holm oak (Quercus ilex) and European beech (Fagus syl- vatica), it was recognized that MT emissions were predominantly controlled by light-dependent mechanisms (Staudt and Seifert, 1995; Tollsten and Müller, 1996; Dindorf et al., 2006). Later on, coniferous trees were also recognized to potentially emit part of their total emission as de novo emissions (Shao et al., 2001; Tarvainen et al., 2005; Moukhtar et al., 2006; Ghirardo et al., 2010; Taipale et al., 2011).

Shao et al. (2001) measured the BVOC emissions from Scots pine (Pinus sylvestris) in darkness and in different light conditions. They found that MT emissions were partly influenced by photosynthetically active radiation (PAR), indicating that observed emissions originate both from storage pools and from direct biosynthesis. Ghirardo et al. (2010) used stable isotope labelling on Norway spruce (Picea abies) and Scots pine and observed that the approximate contribution of de novo MT emissions could range between 25 and $45 \%$ for spruce and 40 and $70 \%$ for pine. Since it has been shown that light-dependent and light-independent emissions happen simultaneously, it has been suggested that the observed MT emission patterns should be regarded as a combination of light-dependent and light-independent emissions instead of only being light-independent for some species (Ghirardo et al., 2010; Taipale et al., 2011; Laffineur et al., 2011; Staudt and Lhoutellier, 2011; Song et al., 2014).

Many emission models face the difficulty of generalizing a species or class of species into one emission potential despite different growing conditions and emission variabilities within species. Even though the BVOC emission patterns tend to be more similar for plants of the same species or genus, variations in emission rates have been observed. Staudt et al. (2001) screened 146 individual holm oak trees, which could be distinguished into three main types with an almost stable BVOC composition. Their results suggest that the observed emission composition is more related to genotypic differences than to environmental impacts. Bäck et al. (2012) sampled branches from 40 mature Scots pine trees from adjacent pine stands. They could divide the trees into three chemotypes which remained fairly stable with the progression of the season. The importance of genetic diversity on observed emission patterns has been further emphasized by Persson et al. (2016), who investigated the emission patterns in genetically identical trees of English oak (Quercus robur), European beech and Norway spruce. Persson et al. (2016) found differences in compound composition between two provenances of spruce but few emission pattern differences for the remaining trees of identical genotypes. Few studies have investigated in situ whether the compounds emitted from different tree species respond similarly with a conditional change in light. Our aim was to investigate how different compounds responded to changing light conditions and whether the response was similar between different tree species.

In this study, we investigated the response of BVOC emission, photosynthetic rates and stomatal conductance of English oak, European beech and Norway spruce to different 
light levels. These species were chosen as they are some of the most common tree species growing in large areas within Europe (Skjøth et al., 2008) and have reported BVOC emission levels exceeding $1 \mu \mathrm{g} \mathrm{gdw}^{1} \mathrm{~h}^{-1}$ (Kesselmeier et al., 1999; Dindorf et al., 2006; Holzke et al., 2006; Pokorska et al., 2012). The study aims to (i) analyse how emissions of different BVOCs respond to changing light levels to identify light-dependent fractions for each compound and (ii) investigate whether there are similar patterns between observed BVOC emission, photosynthetic rates and stomatal conductance. This information could be useful for our understanding of how the emission patterns of common European tree species react to changing light, which could possibly improve the algorithms used in emission models.

\section{Methods}

\subsection{Site description and plant material}

Measurements were carried out on 10-31 July 2015 at the International Phenological Garden (IPG) site Taastrup, Denmark $\left(55^{\circ} 40^{\prime} \mathrm{N}, 14^{\circ} 30^{\prime} \mathrm{E}\right)$, maintained by the Faculty of Science at the University of Copenhagen. The IPG network performs long-term phenological observations at several sites throughout Europe on some of the most common European plant species. Each site was initially provided with up to two individuals per species. The plants used in the network are genetically identical clones, which means the genetic variation between individuals and sites is absent (Chmielewski et al., 2013). At the IPG network site at Taastrup, there are 21 trees from 13 different species and provenances with one or two individuals per species. All trees presented here were planted in 1971. Measurements were performed on two English oaks, one European beech and four Norway spruces, the latter divided into two provenances according to the framework of IPG. These provenances differ in their budburst patterns; one provenance has a budburst approximately 1 week earlier than the other. These provenances of spruce will henceforth be referred to as early spruce and late spruce.

During the measurement period, the weather was quite cold and humid, with an average daily temperature ranging between 13.1 and $18.8^{\circ} \mathrm{C}$ and with a total rainfall of $43.6 \mathrm{~mm}$ during the 3 weeks of measurements. The average temperature and total rainfall for July 2015 was $16.4^{\circ} \mathrm{C}$ and $75 \mathrm{~mm}$ whilst the 10-year (2006-2015) average temperature and rainfall in the area was approximately $18.2{ }^{\circ} \mathrm{C}$ and $71.8 \mathrm{~mm}$ (www.dmi.dk).

\subsection{BVOC measurements at different light levels}

Between 13 and 21 samples were taken from each tree. All measurements were made on the lowest positioned branches (1-2 $\mathrm{m}$ above ground) and on the southwest- or southfacing side of the tree using a portable photosynthesis system (Li-6400 XT, LICOR, NE, USA) equipped either with a LED source leaf chamber (6400-02B) for deciduous trees or a lighted conifer chamber (6400-22L) for the coniferous trees. The ingoing air stream $\left(700 \mathrm{~mL} \mathrm{~min}^{-1}\right)$ into the chambers passed through a hydrocarbon trap and $\mathrm{O}_{3}$ filter to remove organic contaminants and ozone in order to avoid BVOC oxidation before sampling. Measurements were performed during daytime (08:00-16:00). The calculations of net assimilation rates $\left(A_{n}\right)$ and $G_{\mathrm{S}}$ were performed by the instrument software, using the equations presented by von Caemmerer and Farquhar (1981). All measurements were made under fixed environmental conditions. Each leaf or needle twig was acclimated to $400 \mu \mathrm{molCO}_{2} \mathrm{~mol}^{-1}$ air and 50-60\% relative humidity for $1 \mathrm{~h}$ before BVOC emission sampling. The temperature within the chamber was set according to the anticipated average daily temperature (18$23^{\circ} \mathrm{C}$ during the campaign) in order to minimize potential stress emissions from the plant. Each leaf or needle twig was measured under four light levels $(0,500,1000$ and $1500 \mu \mathrm{mol} \mathrm{m}^{-2} \mathrm{~s}^{-1}$ ) by stepwise increasing PAR from 0 to $1500 \mu \mathrm{mol} \mathrm{m}^{-2} \mathrm{~s}^{-1}$. This direction was chosen in order to mimic the daily increase in light intensity. After the first acclimation period of $1 \mathrm{~h}$ at $0 \mu \mathrm{molm} \mathrm{m}^{-2} \mathrm{~s}^{-1}$, an additional 30 min acclimation period was applied after switching to a new light level in order to ensure that the leaf or needle twig had adjusted to the new conditions. This acclimation time was chosen based on preliminary tests showing that leaf photosynthesis remained reasonably stable after $30 \mathrm{~min}$ adjustment to the new light intensity. The BVOC emissions from the trees were collected by extracting air from the chamber outlets into stainless steel cartridges (Markes International Limited, Llantrisant, UK) packed with adsorbents Tenax TA (a porous organic polymer) and Carbograph 1TD (graphitized carbon black). The air extraction was performed using flow-controlled pocket pumps (SKC Ltd., Dorset, UK) with a flow rate of $200 \mathrm{~mL} \mathrm{~min}^{-1}$. Empty chamber blanks were collected every second day with the same chamber conditions in order to account for possible background contamination in the measured samples.

\subsection{BVOC analysis}

The BVOC sample cartridges were sealed with Teflon coated brass caps directly after sampling, stored at $3{ }^{\circ} \mathrm{C}$ and analysed within 8 weeks. A gas chromatograph-mass spectrometer (7890A series GC coupled with a 5975C inert MSD/DS Performance Turbo EI system, Agilent, Santa Clara, CA, USA) was used for analysis after thermal desorption (UNITY2 coupled with an ULTRA autosampler, Markes, Llantrisant, UK). The oven temperature was held at $40^{\circ} \mathrm{C}$ for $1 \mathrm{~min}$, raised to $210^{\circ} \mathrm{C}$ in steps of $5^{\circ} \mathrm{C} \mathrm{min}^{-1}$ and lastly up to $250^{\circ} \mathrm{C}$ in steps of $20^{\circ} \mathrm{C} \mathrm{min}^{-1}$. Helium was used as the carrier gas and the BVOC separation was done with a HP-5 capillary column $(50 \mathrm{~m}$, diameter $0.2 \mathrm{~mm}$ and film thickness $0.33 \mu \mathrm{m})$. The identification and quantification of BVOCs was done using pure standard solutions for isoprene, 
$\alpha$-pinene, camphene, $\beta$-pinene, $\delta$-phellandrene, $\rho$-cymene, 1,8-cineole, ocimene, $\gamma$-terpinene, terpinolene, linalool, aromadendrene, $\alpha$-humulene and nerolidol in methanol (Fluka, Buchs, Switzerland). These standard solutions were injected into adsorbent cartridges in a stream of helium. If there was a compound detected without an available standard, it was identified according to the mass spectra in the NIST library and quantified using $\alpha$-pinene for MTs and $\alpha$-humulene for SQTs. The sample chromatograms were analysed with the MSD Chemstation Data Analysis software (G1701CA C.00.00, 21 December 1999; Agilent Technologies, Santa Clara, CA, USA). Compounds that were found in the empty chamber blanks collected in the field were subtracted from the samples. Only isoprenoids were analysed in this study. Emissions were calculated by using the emission rate equation for the dynamic enclosure technique presented by Ortega and Helmig (2008). For each of the three light levels above 0 , the light-dependent fraction of the total compound emission was calculated as $100 \% \times$ (light emission dark emission)/light emission and used as an indicator for its emission response to changing light. The values ranged from $0 \%$ (no light dependence) to $100 \%$ (compound emitted entirely light dependently).

\subsection{Statistical analysis}

Repeated measures ANOVA tests were computed in the Rstudio software (Rstudio team, 2015, version 0.99.491) in order to test whether the observed emission rates of each compound and the $A_{n}$ or $G_{\mathrm{S}}$ rates differed statistically between the light levels. If a significant effect of light was observed, a simple a priori contrast was used to test which light level was significantly different from the dark measurements. The statistical analyses were done separately for each tree species.

\section{Results}

\subsection{BVOC emission from English oak}

Figure 1 shows the total BVOC emission rate and the compound contributions of the two English oaks at different light levels. The English oak clones in this study had emission rates between 3.5 and $18.3 \mu \mathrm{gdw}^{1} \mathrm{~h}^{-1}$ at a light level of $1000 \mu \mathrm{mol} \mathrm{m}^{-2} \mathrm{~s}^{-1}$ and a set temperature range of 18 $21^{\circ} \mathrm{C}$. The first oak had a statistically significant increase of the total emission across light levels, whilst the emission rate of the second oak saturated at $1000 \mu \mathrm{mol} \mathrm{m}^{-2} \mathrm{~s}^{-1}$. These emission rates are in line with the standardized emission rates reported by previous studies (Isidorov et al., 1985; Kesselmeier and Staudt, 1999; Pokorska et al., 2012; Persson et al., 2016) (Table 1). Between one and seven compounds were detected at the measured light levels and the detected compounds were isoprene, tricyclene, $\alpha$-pinene, camphene, 3-carene, limonene and eucalyptol. The main emit- ted compound was isoprene, with no emission during darkness and an emission rate between 2.3 and $19.8 \mu \mathrm{g} \mathrm{gdw}^{1} \mathrm{~h}^{-1}$ for oak 1 and between 1.3 and $9.3 \mu \mathrm{gdw}^{1} \mathrm{~h}^{-1}$ for oak 2 at light levels of $500-1500 \mu \mathrm{mol} \mathrm{m}^{-2} \mathrm{~s}^{-1}$. The relative contribution of isoprene to the total emission with light levels at or above $500 \mu \mathrm{mol} \mathrm{m}^{-2} \mathrm{~s}^{-1}$ was $>96 \%$ (Fig. 1). At a light level of $0 \mu \mathrm{mol} \mathrm{m}{ }^{-2} \mathrm{~s}^{-1}$, the main detected compounds were limonene and $\alpha$-pinene. The emissions of these MTs remained stable across measured PAR levels, with emission rates of $<0.1 \mu \mathrm{gdw}^{1} \mathrm{~h}^{-1}$ at all levels (see Appendix A for absolute values).

\subsection{BVOC emission from European beech}

In contrast to English oak, European beech showed a smaller and non-significant response of the total isoprenoid emission rate to a change in light (Table 1, Fig. 2). Beech emitted between one and five detected isoprenoids in darkness and between four and eight with light. Detected compounds were tricyclene, $\alpha$-pinene, camphene, sabinene, 3 carene, limonene, eucalyptol and caryophyllene. Sabinene was not detected at $0 \mu \mathrm{molm} \mathrm{m}^{-2} \mathrm{~s}^{-1}$ but was the main emitted compound with light, increasing from $66 \%$ of the total emission at $500 \mu \mathrm{mol} \mathrm{m}^{-2} \mathrm{~s}^{-1}$ to $76 \%$ at $1500 \mu \mathrm{mol} \mathrm{m}^{-2} \mathrm{~s}^{-1}$. Limonene was the main emitted compound in darkness. The amount of limonene released remained fairly stable across the studied light levels and ranged between 0.06 and $0.09 \mu \mathrm{gdw}^{1} \mathrm{~h}^{-1}$. The other emitted MTs did not change their emission patterns with increasing light. At light levels 1000 and $1500 \mu \mathrm{mol} \mathrm{m}^{-2} \mathrm{~s}^{-1}$, the SQT caryophyllene was released, with the highest emissions at $1500 \mu \mathrm{gdw}^{1} \mathrm{~h}^{-1}$ (see Appendix A for absolute values, Fig. 2).

\subsection{BVOC emission from Norway spruce}

Figure $3 \mathrm{a}$ and $\mathrm{b}$ show the emission rate and the compound contribution with increasing light levels for early spruce and late spruce, respectively. All four spruce trees emitted isoprene with light $(P<0.001$ for early spruce 1 and late spruce 1 and $2, P>0.1$ for early spruce 2 ) with a contribution to the total emission of 30-65\%. In contrast, limonene and $\alpha$-pinene were emitted both in darkness as well as with light, but with lower absolute emissions in darkness (see Appendix A for absolute values; Fig. 3). Early spruce 1 had an emission rate of $0.5-0.6 \mu \mathrm{gdw}^{1} \mathrm{~h}^{-1}$, whilst early spruce 2 ranged between 0.1 and $0.4 \mu g g d w^{1} h^{-1}$ with light. Between four and nine isoprenoids were detected, which were isoprene, tricyclene, $\alpha$-pinene, camphene, $\beta$-pinene, 3 carene, limonene, eucalyptol, linalool, $\alpha$-farnesene and $\beta$ farnesene. Only one of the two early spruce trees emitted linalool and SQTs. The main detected compound for both trees was isoprene, followed by limonene. The total emission from early spruce 1 saturated at $500 \mu \mathrm{mol} \mathrm{m}^{-2} \mathrm{~s}^{-1}$ with no significant change with increasing light $(P>0.1)$, whilst early spruce 2 decreased its total emission to $0.1 \mu \mathrm{ggdw}{ }^{1} \mathrm{~h}^{-1}$ 


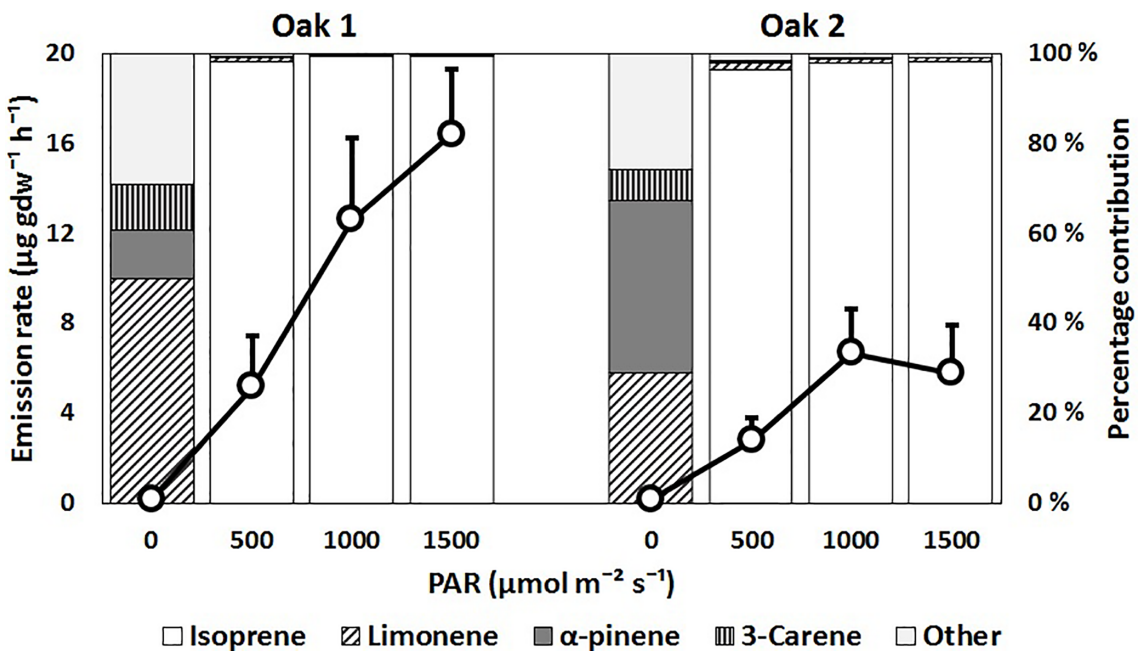

Figure 1. The total BVOC emission rate of two individual English oak trees (open circles) and the relative contribution of the major compounds at four intensities of photosynthetically active radiation (PAR). The error bars show the SD, $n=3-5$ leaves. The category "Other" contains the compounds tricyclene, camphene and eucalyptol.

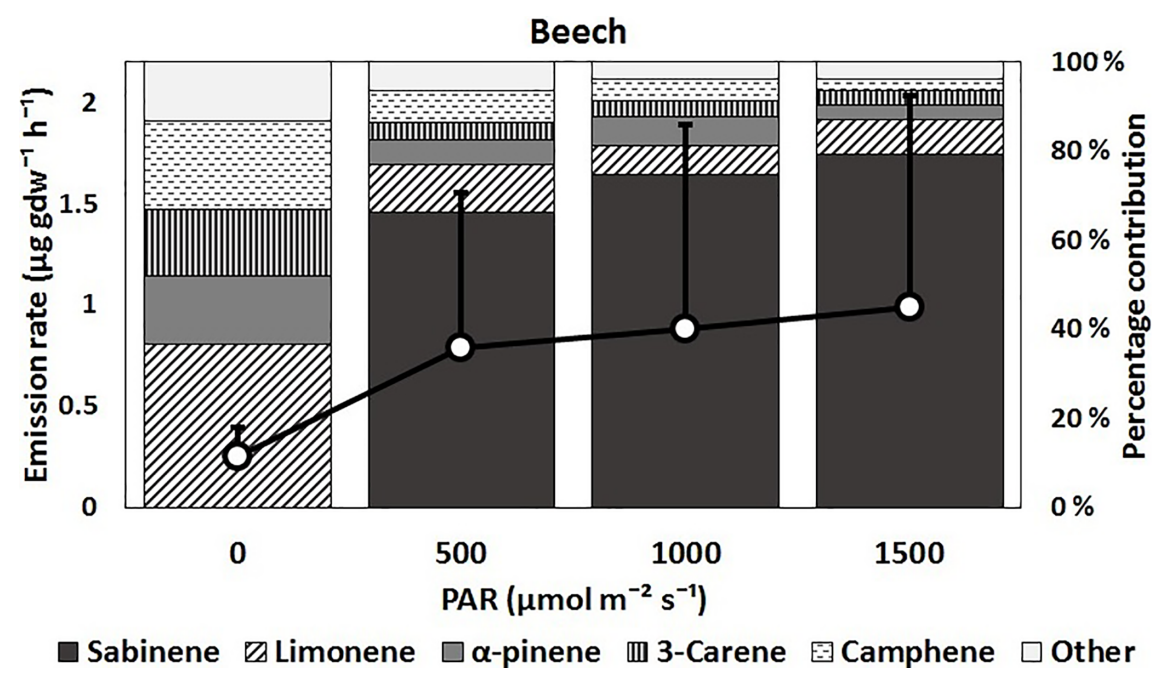

Figure 2. The total BVOC emission rate for European beech (open circles) and the relative contribution of the major compounds at four intensities of photosynthetically active radiation (PAR). The error bars show the SD, $n=4-6$ leaves. The category "Other" contains the compounds tricyclene and eucalyptol.

at $1000 \mu \mathrm{mol} \mathrm{m}^{-2} \mathrm{~s}^{-1}$ and then increased again somewhat to $0.3 \mu \mathrm{ggdw}^{1} \mathrm{~h}^{-1}$ at $1500 \mu \mathrm{mol} \mathrm{m}^{-2} \mathrm{~s}^{-1}$ (Fig. 3a). Late spruce emitted 2 to 10 isoprenoids at all light levels and the detected compounds were isoprene, tricyclene, $\alpha$-pinene, camphene, $\beta$-pinene, 3 -carene, $\alpha$-terpinene, limonene, eucalyptol and $\gamma$-terpinene. $\beta$-Pinene was emitted by both provenances of Norway spruce, but with higher emissions rates from late spruce in combination with higher emissions of $\alpha$-pinene. Only late spruce 1 emitted tricyclene and $\alpha$-terpinene and only at PAR levels of 1000 and $1500 \mu \mathrm{mol} \mathrm{m} \mathrm{m}^{-2} \mathrm{~s}^{-1}$. Both trees had an increase in total emission up to $1000 \mu \mathrm{mol} \mathrm{m}^{-2} \mathrm{~s}^{-1}$, with a decrease in emissions at $1500 \mu \mathrm{mol} \mathrm{m}^{-2} \mathrm{~s}^{-1}$ for late spruce 1 . Late spruce 1 reached its peak emission of $2.2 \mu \mathrm{ggdw}^{1} \mathrm{~h}^{-1}$ at $1000 \mu \mathrm{mol} \mathrm{m}^{-2} \mathrm{~s}^{-1}$, whilst late spruce 2 had a stable emission between 0.6 and $0.9 \mu \mathrm{gdw}^{1} \mathrm{~h}^{-1}$ with light. The emitted compounds from late spruce 1 followed a similar emission pattern as the total emission rate, but for late spruce 2 all compounds except $\alpha$-pinene, eucalyptol and $\gamma$-terpinene remained fairly stable with increase in light (Appendix A, Fig. 3b).

\subsection{Light-dependent fractions of different compounds}

Whilst some compounds like isoprene and sabinene were specific for different tree species, the compounds $\alpha$-pinene, camphene, 3-carene, limonene and eucalyptol were emitted 
Early spruce 2

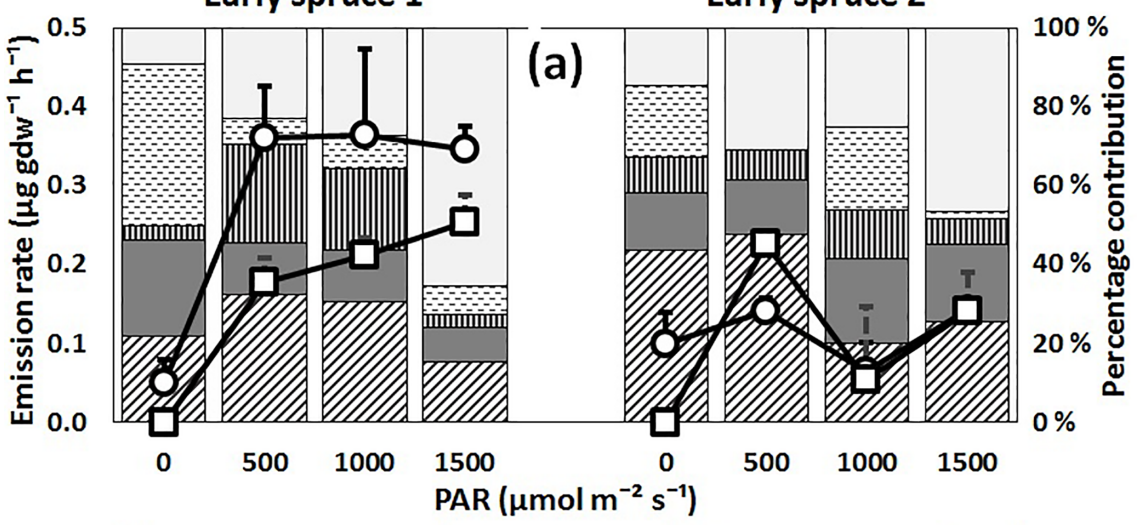

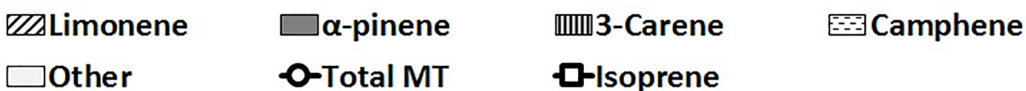

Late spruce 1

Late spruce 2

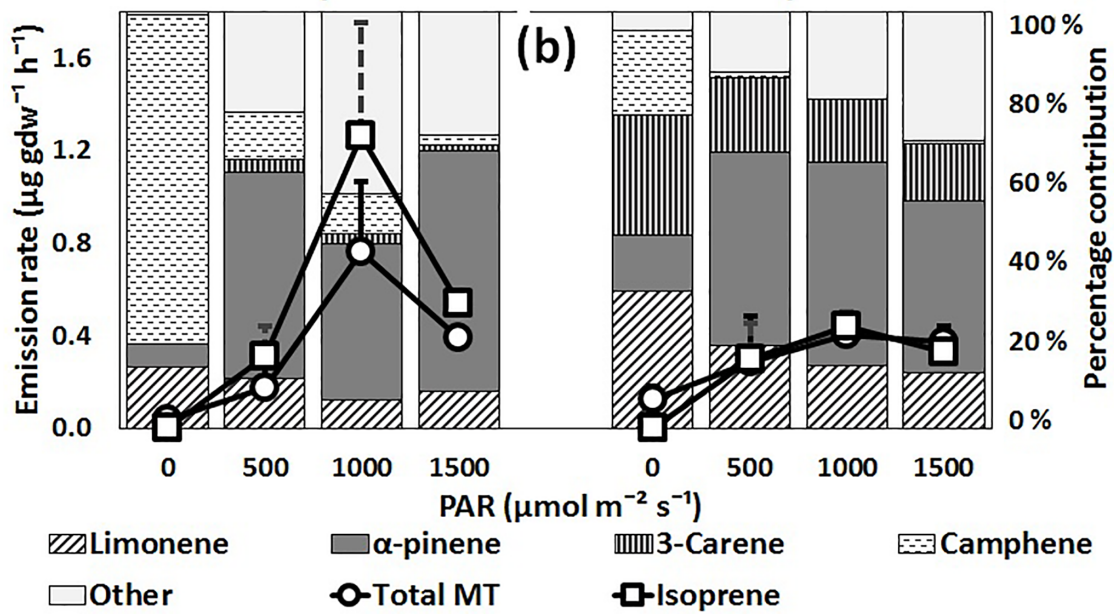

Figure 3. The total BVOC emission rate from two individuals of Norway spruce with (a) an early budburst and (b) a late budburst and the relative contribution of the major compounds at four intensities of photosynthetically active radiation (PAR). The open circles show total monoterpene emission, whilst the open squares show isoprene emission of all measured twigs $(n=3-6$ twigs). The error bars are the $\mathrm{SD}$ of the data. The category "Other" contains the compounds tricyclene, $\beta$-pinene, eucalyptol and linalool for early spruce and tricyclene, $\beta$-pinene, $\alpha$-terpinene eucalyptol and $\gamma$-terpinene for late spruce.

from all of the measured leaves or needle twigs. As these compounds were emitted at different light levels, we will assess the light dependency of these compounds. The lightdependent fraction for isoprene was $100 \%$ for all of the isoprene-emitting trees (Table 2). The same fraction and significance were also found for sabinene emission from beech $(P<0.001$, Table 2). The light response for the total MT emission differed between species. Whilst the oaks and the second early spruce showed little or no response to light, the beech and the remaining spruce trees increased their emissions. The light-dependent fraction of other MTs, however, depended on the compound and the tree species. Camphene had a significant change in emission from darkness to $500 \mu \mathrm{mol} \mathrm{m}^{-2} \mathrm{~s}^{-1}$ for early and late spruce 2 , but for remain- ing light levels camphene showed no clear light dependency for any of the measured trees (Appendix A, Tables 1 and 2).

For the oaks, no compounds other than isoprene showed a significant light dependency. For beech, some compounds like camphene, 3-carene, limonene and eucalyptol increased the light-dependent fractions with higher light levels, but without this being a significant increase in its emissions (Appendix A, Tables 1 and 2).

The two provenances of spruce showed a higher lightdependent fraction for MTs in comparison to the broadleaved trees. Early spruce 1 and late spruce 1 showed lightdependent fractions of 76-86 and 67-94\%, respectively, for the total MT emission (Table 2). Both trees had high lightdependent fractions for the compounds $\alpha$-pinene, 3-carene and eucalyptol. For early spruce 1, eucalyptol increased its 

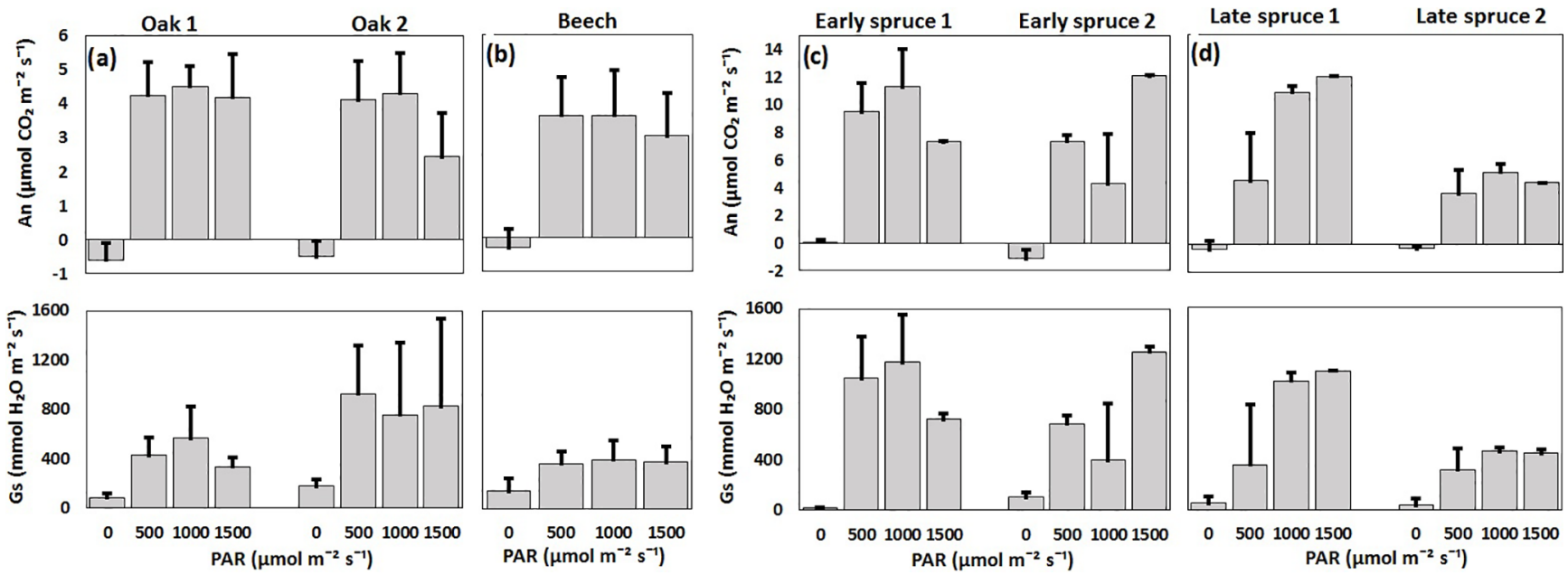

Figure 4. The net assimilation rate $\left(A_{n}\right)$ and stomatal conductance $\left(G_{\mathrm{S}}, \mathrm{mmol} \mathrm{H}_{2} \mathrm{Om}^{-2} \mathrm{~s}^{-1}\right)$ of (a) two individuals of English oak, (b) European beech, (c) two individuals of Norway spruce with an early budburst (early spruce) and (d) two individuals of Norway spruce with a late budburst (late spruce). The values are averages $\pm \operatorname{SD}(n=13-21)$.

Table 1. The $P$ values from repeated measures ANOVA tests on the emission rate of each compound, photosynthetic rates $\left(A_{n}\right)$ and stomatal conductance $\left(G_{\mathrm{S}}\right)$ in response to an increase in light intensity. The trees that were measured were two individuals of English oak $(Q u e r c u s$ robur), one European beech (Fagus sylvatica), two individuals of Norway spruce (Picea abies) with an early budburst (early spruce) and two individuals of Norway spruce with a late budburst (late spruce). $P$ values marked in bold show statistically significant values $(P<0.05)$. Isoprene was not detected from the European beech tree.

\begin{tabular}{lrrrrrrr}
\hline Compound & Oak 1 & Oak 2 & Beech & Early spruce 1 & Early spruce 2 & Late spruce 1 & Late spruce 2 \\
\hline Isoprene & $<\mathbf{0 . 0 0 1}$ & $<\mathbf{0 . 0 0 1}$ & - & $<\mathbf{0 . 0 0 1}$ & 0.13 & $<\mathbf{0 . 0 0 1}$ & $<\mathbf{0 . 0 0 1}$ \\
$\alpha$-Pinene & 0.15 & 0.99 & 0.98 & $\mathbf{0 . 0 2}$ & $\mathbf{0 . 0 3}$ & 0.18 & $<\mathbf{0 . 0 0 1}$ \\
Camphene & 0.57 & 0.88 & 0.35 & 0.56 & $\mathbf{0 . 0 1}$ & 0.55 & $\mathbf{0 . 0 1}$ \\
3-Carene & 0.43 & 0.90 & 0.92 & $\mathbf{0 . 0 1}$ & 0.29 & $\mathbf{0 . 0 5}$ & 0.36 \\
Limonene & 0.66 & 0.97 & 0.65 & $<\mathbf{0 . 0 0 1}$ & 0.46 & 0.59 & 0.40 \\
Eucalyptol & 0.39 & 0.86 & 0.61 & $\mathbf{0 . 0 0 4}$ & $\mathbf{0 . 0 1}$ & $<\mathbf{0 . 0 0 1}$ & 0.07 \\
\hline Total BVOCs & $<\mathbf{0 . 0 0 1}$ & $<\mathbf{0 . 0 0 3}$ & 0.87 & $<\mathbf{0 . 0 0 1}$ & 0.23 & $\mathbf{0 . 0 1}$ & $\mathbf{0 . 0 0 3}$ \\
$A_{n}$ & $<\mathbf{0 . 0 0 1}$ & $<\mathbf{0 . 0 0 1}$ & $\mathbf{0 . 0 0 1}$ & $\mathbf{< . 0 0 1}$ & $\mathbf{0 . 0 3}$ & $\mathbf{0 . 0 0 1}$ & $<\mathbf{0 . 0 0 1}$ \\
$G_{\mathrm{S}}$ & $\mathbf{0 . 0 2}$ & 0.23 & 0.25 & $\mathbf{0 . 0 0 7}$ & 0.13 & $\mathbf{0 . 0 2}$ & $<\mathbf{0 . 0 0 1}$ \\
\hline
\end{tabular}

light-dependent fraction with increasing light levels. For late spruce 1 there was a higher percentage of light dependency for $\alpha$-pinene, but only limonene increased in light dependency with increasing light. Early spruce 2 had low lightdependent fractions for all compounds except eucalyptol, whilst late spruce 2 had high light-dependent fractions for $\alpha$ pinene and eucalyptol. Although several of the above mentioned compounds from early spruce 2 and late spruce 2 showed a light dependency, this light dependency did not change with a change in light level (Table 2).

\subsection{Photosynthesis and stomatal conductance}

For oak, the assimilation $\left(A_{n}\right)$ rates were fairly similar between the two trees, ranging from -0.6 to $-0.5 \mu \mathrm{molCO}_{2} \mathrm{~m}^{-2} \mathrm{~s}^{-1}$ in darkness and from 2.4 to $4.5 \mu \mathrm{molCO}_{2} \mathrm{~m}^{-2} \mathrm{~s}^{-1}$ with light (Fig. 4a, Table 1). The dif- ference was larger for the stomatal conductance $\left(G_{\mathrm{S}}\right)$ : oak 1 showed a significant difference with increasing light $(P<$ $0.05)$ in comparison to oak 2 , which showed higher internal variation $(P>0.2)$. In regards to their photosynthetic and stomatal conductance ranges, they are comparable with studies performed on oak leaves grown in either shaded or semi-shaded conditions (Morecroft and Roberts, 1999; Valladares et al., 2002). For beech, $A_{n}$ increased from darkness to the PAR level of $500 \mu \mathrm{mol} \mathrm{m}^{-2} \mathrm{~s}^{-1}(P<0.001)$ but did not show a response to further increase in light $(P>0.6)$. $A_{n}$ was between 3 and $3.6 \mu \mathrm{molCO} \mathrm{m}^{-2} \mathrm{~s}^{-1}$ with light and $-0.3 \mu \mathrm{molCO} \mathrm{m}_{2} \mathrm{~m}^{-2} \mathrm{~s}^{-1}$ in darkness, whilst $G_{\mathrm{S}}$ ranged between 100 and $400 \mathrm{mmolH}_{2} \mathrm{Om}^{-2} \mathrm{~s}^{-1}$ for all light levels (Fig. 4b).

For early spruce $1, \quad A_{n}$ was between 9.5 and $11.3 \mu \mathrm{molCO}_{2} \mathrm{~m}^{-2} \mathrm{~s}^{-1}$ at a light level of 
Table 2. The percentage of emissions that are dependent on light (PAR, in $\mu \mathrm{mol} \mathrm{m} \mathrm{m}^{-2} \mathrm{~s}^{-1}$ ), as determined for the total monoterpene (MT) emission and for the main emitted compounds. The percentage was calculated as $100 \% \times$ (light emissions - dark emissions)/light emissions. The numbers in brackets are the standard error of the mean. The trees that were measured were two individuals of English oak (Quercus robur), one European beech (Fagus sylvatica), two individuals of Norway spruce (Picea abies) with an early budburst (early spruce) and two individuals of Norway spruce with a late budburst (late spruce). No data (n.d.) indicates compounds that were not detected in any sample or light level for that particular tree.

\begin{tabular}{lrrrrrrrrr}
\hline Tree & PAR & Total MT & Isoprene & $\alpha$-Pinene & Camphene & Sabinene & 3-Carene & Limonene & Eucalyptol \\
\hline Oak 1 & 500 & $0(0)$ & $100(0)$ & $0(0)$ & $17(10)$ & n.d. & $0(0)$ & $0(0)$ & $0(0)$ \\
& 1000 & $4(4)$ & $100(0)$ & $0(0)$ & $17(17)$ & n.d. & $11(11)$ & $5(5)$ & $0(0)$ \\
& 1500 & $10(10)$ & $100(0)$ & $0(0)$ & $40(21)$ & n.d. & $0(0)$ & $9(9)$ & $3(3)$ \\
Oak 2 & 500 & $0(0)$ & $100(0)$ & $0(0)$ & $15(10)$ & n.d. & $21(21)$ & $0(0)$ & $0(0)$ \\
& 1000 & $15(15)$ & $100(0)$ & $16(16)$ & $20(20)$ & n.d. & $31(18)$ & $15(15)$ & $13(13)$ \\
& 1500 & $0(0)$ & $100(0)$ & $12(6)$ & $8(8)$ & n.d. & $0(0)$ & $0(0)$ & $0(0)$ \\
\hline Beech & 500 & $6(6)$ & n.d. & $0(0)$ & $0(0)$ & $100(0)$ & $0(0)$ & $0(0)$ & $0(0)$ \\
& 1000 & $23(10)$ & n.d. & $20(20)$ & $4(4)$ & $100(0)$ & $15(15)$ & $0(0)$ & $0(0)$ \\
& 1500 & $52(26)$ & n.d. & $7(7)$ & $31(31)$ & $100(0)$ & $50(6)$ & $77(23)$ & $19(19)$ \\
\hline Early & 500 & $81(5)$ & $100(0)$ & $64(9)$ & $6(6)$ & n.d. & $88(10)$ & $84(1)$ & $89(6)$ \\
spruce 1 & 1000 & $76(6)$ & $100(0)$ & $54(8)$ & $10(10)$ & n.d. & $79(18)$ & $79(1)$ & $89(5)$ \\
& 1500 & $86(3)$ & $100(0)$ & $60(8)$ & $14(9)$ & n.d. & $73(14)$ & $76(3)$ & $91(4)$ \\
\hline Early & 500 & $18(4)$ & $100(0)$ & $20(8)$ & $0(0)$ & n.d. & $15(15)$ & $18(3)$ & $69(3)$ \\
spruce 2 & 1000 & $0(0)$ & $100(0)$ & $3(3)$ & $8(8)$ & n.d. & $26(26)$ & $0(0)$ & $62(4)$ \\
& 1500 & $19(14)$ & $100(0)$ & $43(10)$ & $0(0)$ & n.d. & $7(7)$ & $0(0)$ & $74(3)$ \\
\hline Late & 500 & $67(14)$ & $100(0)$ & $98(2)$ & $12(12)$ & n.d. & $100(0)$ & $31(25)$ & $95(5)$ \\
spruce 1 & 1000 & $94(3)$ & $100(0)$ & $67(33)$ & $45(33)$ & n.d. & $100(0)$ & $65(32)$ & $100(0)$ \\
Late & 1500 & $87(3)$ & $100(0)$ & $98(2)$ & $0(0)$ & n.d. & $100(0)$ & $79(16)$ & $100(0)$ \\
spruce 2 & 500 & $26(15)$ & $100(0)$ & $85(1)$ & $0(0)$ & n.d. & $16(13)$ & $8(8)$ & $57(22)$ \\
& 1000 & $68(8)$ & $100(0)$ & $91(3)$ & $0(0)$ & n.d. & $40(8)$ & $37(18)$ & $78(14)$ \\
\hline & 1500 & $57(13)$ & $100(0)$ & $85(5)$ & $0(0)$ & n.d. & $23(12)$ & $20(20)$ & $77(15)$ \\
\hline
\end{tabular}

500 and $1000 \mu \mathrm{molm}^{-2} \mathrm{~s}^{-1}$, which decreased to $7.3 \mu \mathrm{molCO}_{2} \mathrm{~m}^{-2} \mathrm{~s}^{-1}$ at $1500 \mu \mathrm{mol} \mathrm{m}^{-2} \mathrm{~s}^{-1}$. $G_{\mathrm{S}}$ followed a similar pattern, ranging from 1000 to $1200 \mathrm{mmol} \mathrm{H}_{2} \mathrm{Om}^{-2} \mathrm{~s}^{-1}$ at a light level of 500 and $1000 \mathrm{mmol} \mathrm{m}^{-2} \mathrm{~s}^{-1}$ and decreased to $700 \mathrm{mmol} \mathrm{H}_{2} \mathrm{O} \mathrm{m}^{-2} \mathrm{~s}^{-1}$ at a light level of $1500 \mu \mathrm{molm}^{-2} \mathrm{~s}^{-1}$ (Fig. 4c, Table 1). A similar pattern as the BVOC emissions for early spruce 2 could also be seen in the rates of $A_{n}$ and $G_{\mathrm{S}}$ with lower values coinciding with lower emissions, but which was significant only for $A_{n}$ (Table 1). Late spruce 1 had a higher emission rate in comparison to late spruce 2, which was also evident for the $A_{n}$ and $G_{\mathrm{S}}$ rates. Whilst late spruce 1 showed an increase in both $A_{n}$ and $G_{\mathrm{S}}$ with increasing light levels $(P<0.05)$, late spruce 2 did not show any clear response to increasing light above $500 \mu \mathrm{mol} \mathrm{m}^{-2} \mathrm{~s}^{-1}$ $(P>0.2)$. Late spruce 1 had an average $A_{n}$ rate of 4.5-10.9 $\mu \mathrm{molCO}_{2} \mathrm{~m}^{-2} \mathrm{~s}^{-1}$ and an average $G_{\mathrm{S}}$ rate of $400-$ $1100 \mathrm{mmol} \mathrm{H}_{2} \mathrm{O} \mathrm{m}^{-2} \mathrm{~s}^{-1}$ with light. For the second spruce, the $A_{n}$ and $G_{\mathrm{S}}$ rates were stable at an average range of 3.6-5.1 $\mathrm{mmol} \mathrm{CO}_{2} \mathrm{~m}^{-2} \mathrm{~s}^{-1}$ and 300-500 $\mathrm{mmol} \mathrm{H}_{2} \mathrm{O} \mathrm{m}^{-2} \mathrm{~s}^{-1}$ with light (Fig. 4d).

\section{Discussion}

Light plays an important role as a driver of BVOC emissions, particularly in regards to de novo emissions. Overall, the investigated trees showed a similar response to light in their light-dependent BVOC emissions, $A_{n}$ and $G_{\mathrm{S}}$, but the light level at which these processes saturate could vary for individual leaves or needle twigs.

\subsection{Responses of BVOC emissions to changing light conditions}

Isoprene was the main emitted compound for the measured oak trees which showed a clear response to increasing light. This increasing emission with light has also been confirmed by other performed studies (Tingey et al., 1981; Lehning et al., 1999). For beech, the main emitted compound was sabinene, which also responded to increasing light. A similarity which was found for the oaks and the beech was that, apart from their main emitted compounds, the emission rate of other MTs did not show any significant response with increasing light $(P>0.05)$. This observation would suggest that the emission of MTs from these decid- 
uous trees should be regarded as light independent instead of light dependent, dividing the emissions into light-dependent and light-independent fractions. For coniferous tree species, which are known to have storage structures contributing to a considerable light-independent emission, a division of the emissions into light-dependent and light-independent fractions has been suggested (Ghirardo et al., 2010). Although similar structures are absent in the broadleaf species studied here, the results suggest that these species also have a lightindependent fraction.

The two provenances of spruce had different responses of their emitted compounds with an increase in light, where the light-dependent fraction of the total MT emission increased for all trees except for early spruce 2 . Regarding separate compounds, they were also shown to respond differently with an increase in light depending on the individual tree. The compound camphene showed significant emission responses from early spruce 2 and late spruce 2 , but only going from darkness to $500 \mu \mathrm{mol} \mathrm{m}{ }^{-2} \mathrm{~s}^{-1}$. For the remaining trees, there was no clear camphene emission response to an increase in light. This suggests that this compound should be considered to be light independent when emission rates are to be modelled. Early spruce 1 showed light-dependent fractions from $\alpha$-pinene, 3 -carene, limonene and eucalyptol, but with eucalyptol was the only MT compound which continued to increase its light-dependent fraction with increasing light intensity. A similar light dependency of eucalyptol has also been found for emissions from Abies alba (Moukhtar et al., 2006). Early spruce 2 showed light-dependent fractions from $\alpha$-pinene, camphene and eucalyptol. However, as the amount of samples taken on early spruce 2 were few, it is difficult to draw any clear conclusions for this tree. Both the late spruce trees had light-dependent emissions of $\alpha$-pinene and eucalyptol. Late spruce 1 also showed light-dependent fractions for 3-carene going from darkness to light, but the overall emission rate of this compound was low and of little importance in regard to the general compound contribution. For late spruce 2, $\alpha$-pinene and camphene showed significant emission increases from darkness to $500 \mu \mathrm{mol} \mathrm{m}^{-2} \mathrm{~s}^{-1}$. The response of late spruce 2 might, however, be masked by high internal emission variation at $500 \mu \mathrm{mol} \mathrm{m}^{-2} \mathrm{~s}^{-1}$.

Regarding the light dependency of MT emissions, there are several studies which have suggested that both de novo and storage pool emissions can occur within different tree species (Dindorf et al., 2006; Moukhtar et al., 2006; Ghirardo et al., 2010). Our study shows that different compounds respond differently to a change in light and that compounds like camphene have similar emission responses for English oak, European beech and Norway spruce and that all of the measured trees released isoprenoids in darkness, with emissions ranging from 0 to $0.4 \mu \mathrm{gdw}^{1} \mathrm{~h}^{-1}$ for the broadleaf trees and from 0.01 to $0.22 \mu \mathrm{gdw}^{1} \mathrm{~h}^{-1}$ for the provenances of spruce. This would indicate that species such as English oak and European beech, which are considered to lack specific storage compartments, have a capacity to store com- pounds in the mesophyll, which has also been suggested by other studies (Niinemets and Reichstein, 2003; Holopainen and Gershenzon, 2011). In a study by Loreto et al. (2000), ${ }^{13} \mathrm{C}$ labelling was used on Holm oak (Quercus ilex) with and without illumination and found that the newly synthesized compounds could continue to be emitted long after initiation of darkness. It was suggested that the volatile compounds could be non-specifically stored within the plant leaves, either in the lipid phase or in the aqueous phase. Furthermore, Bäck et al. (2005) did a modelling study on Scots pine where a mesophyll pool was included, which enabled them to better capture diurnal and seasonal emission trends of MT emissions. These results suggest that as there might exist nonspecific storage within the leaf tissue, de novo emitting tree species need to be considered to have storage pools in emission models as well. However, with the current experimental setup, it is only possible to make assumptions of the relative contributions of de novo sources and storage pools. This is otherwise often tested by using ${ }^{13} \mathrm{CO}_{2}$ labelling, where de novo emissions would have ${ }^{13} \mathrm{C}$ incorporated into their compound structures after a pulse of labelled ${ }^{13} \mathrm{CO}_{2}$ (Ghirardo et al., 2010). But by using genetically identical trees and fixed environmental conditions inside the measurement chamber, it has been possible to study the emission response of different compounds to an increase in light intensity.

As models divide plants into categories or plant functional types depending on the growing conditions to which they have adapted (Schurgers et al., 2011; Guenther et al., 2012), an approach looking at the emission patterns of separate compounds would perhaps improve emission models further. If the plants are also categorized into the compound emission response, the model would perhaps provide more realistic values by dividing the compounds into light-dependent or light-independent fractions. We would therefore strongly suggest that more studies assessing light dependency of different compounds are performed on similar or different tree species in order to verify this light dependency of the compounds.

\subsection{Emission pattern variation and shade adaptation of the leaves and needle twigs}

The European tree species presented here have distinct emission patterns: English oak is a known high isoprene emitter, European beech mainly emits MTs such as sabinene and Norway spruce is known to emit both isoprene and MTs (Dindorf et al., 2006; Ghirardo et al., 2010; Pokorska et al., 2012). Between 96 and $99 \%$ of the total emission for oak consisted of isoprene, followed by MTs such as limonene and $\alpha$-pinene. This compound contribution has not only been stable over 3 years of measurements on these genetically identical trees, but it is also in agreement with measurements at other sites (Staudt et al., 2001; Persson et al., 2016; van Meeningen et al., 2016). This would suggest that even if environmental factors such as temperature or light influence the total emis- 
sion from oak, these do not alter the compound contribution to a great extent (Staudt et al., 2001; van Meeningen et al., 2016).

There were big differences in emission amounts between beech leaves, making it difficult to see any clear increase in BVOC emissions with an increase in light. When the light level exceeded $1000 \mathrm{mmol} \mathrm{m}^{-2} \mathrm{~s}^{-1}$, there was also an increase in SQT emissions. The total emission rates are in the lower ranges in comparison to other studies with standardized emission rates (Moukhtar et al., 2005; Dindorf et al., 2006, and references therein). This could be because all samples were taken on the lowest positioned branches of the tree. In the study made by Persson et al. (2016) from the same site performed in 2013, the emission rates were taken at three different height levels within the canopy of all the above mentioned trees. For the European beech, the standardized emission rates were much higher at the top of the canopy in comparison to lower levels, with an average standardized emission of $26.5 \mu \mathrm{gdw}^{1} \mathrm{~h}^{-1}$ at the top of the canopy and $3.6 \mu \mathrm{gdw}^{1} \mathrm{~h}^{-1}$ at the bottom (Persson et al., 2016). The lower emission rate found in this study could be caused by more shade-adapted leaves, with a possible lower capacity to respond to high increases in light. The levels of $A_{n}$ and $G_{\mathrm{S}}$ presented here are comparable with other studies performed on leaves adapted to shaded or semi-shaded conditions (Valladares et al., 2002; Warren et al., 2007; Scartazza et al., 2016). It would be advisable to make more measurements at the top of the canopy in comparison to the lower levels in order to not underestimate the emission potentials for European beech.

There were distinct differences in emission spectra between the two provenances of Norway spruce. The main emitted compound for both provenances was isoprene, but regarding the emitted MTs early spruce was mainly a limonene emitter whilst late spruce emitted $\alpha$-pinene. This emission pattern difference between provenances has been observed in three separate studies performed at the same site (Persson et al., 2016, for 2013, unpublished data for 2014, current study for 2015). Furthermore, late spruce also emitted $\beta$-pinene at a higher rate than the early spruce trees, whilst the compounds $\alpha$-terpinene and $\gamma$-terpinene were only emitted by late spruce. This would suggest that for different provenances of the same species, different compound adaptations might exist. Studies on other tree species have suggested that trees can be divided into chemotypes depending on their emission patterns and that the compound contribution of these chemotypes remains fairly stable over time (Staudt et al., 2001; Bäck et al., 2012).

The average emission rates at $1000 \mu \mathrm{mol} \mathrm{m}^{-2} \mathrm{~s}^{-1}$ ranged between 0.1 and $0.6 \mu \mathrm{gdw}^{1} \mathrm{~h}^{-1}$ for early spruce and between 0.9 and $2.2 \mu \mathrm{g} \mathrm{gdw}^{1} \mathrm{~h}^{-1}$ for late spruce, which were in range of previous studies (Kesselmeier and Staudt, 1999; Grabmer et al., 2006). The four light levels that were tested did not provide enough information to address the light response entirely. More points taken between 0 and
$500 \mu \mathrm{mol} \mathrm{m}{ }^{-2} \mathrm{~s}^{-1}$ would therefore be advisable in order to fully understand the change in emission amounts. The second early spruce tree showed more fluctuation between different light levels, possibly as a response to stress exposure. When measurements were performed on this tree in 2013, the needles on the lowest branches dried and fell off after a prolonged period without rain in the middle of July (Persson et al., 2016). In 2014, when measurements were performed again, the lower twigs had still not recovered and it was not possible to make any measurements on that level (unpublished data). In 2015, new twigs had started to emerge again on early spruce 2 , but twigs were small and visibly less healthy. In comparison to the 10-year average weather conditions at the site, July in 2015 has had approximately the same amount of rainfall but was almost $2{ }^{\circ} \mathrm{C}$ colder. It is likely that the weather conditions had an effect on the emission results. However, as all trees have had the same exposure, it does not fully explain the different responses between trees. With less material to make measurements on and with possible recovery from stress, it is difficult to fully capture the release of BVOC emission from early spruce 2 . The average $A_{n}$ rates for early spruce and late spruce were between 4.3 and 12.1 and between 3.6 and $12 \mu \mathrm{molCO}_{2} \mathrm{~m}^{-2} \mathrm{~s}^{-1}$ respectively, whilst the $G_{\mathrm{S}}$ rates ranged between 400 and $1200 \mathrm{mmol} \mathrm{H}_{2} \mathrm{O} \mathrm{m}^{-2} \mathrm{~s}^{-1}$ for early spruce and between 300 and $1000 \mathrm{mmol} \mathrm{H}_{2} \mathrm{Om}^{-2} \mathrm{~s}^{-1}$ for late spruce. These values are in range or slightly higher than reported in other studies (Le Thiec et al., 1994; Roberntz and Stockfors, 1998; Špunda et al., 2005). Early spruce 1 and late spruce 2 behaved in a similar fashion as European beech with a tendency to stabilize their $A_{n}$ and $G_{\mathrm{S}}$ rates at a light level of $500 \mu \mathrm{mol} \mathrm{m}{ }^{-2} \mathrm{~s}^{-1}$, indicating some shade adaptation of the selected needle twigs. Late spruce 1 increased both in $A_{n}$ and $G_{\mathrm{S}}$ rates with light, possible because the tree stands more exposed than the others in the northeast corner of the IPG site and therefore is more light adapted in comparison to the other trees. Early spruce 2 showed the same fluctuating pattern in $A_{n}$ and $G_{\mathrm{S}}$ rates as with the observed BVOC emissions, most likely due to a restricted sample size and previous effect of drought stress on the tree.

\section{Summary and conclusions}

Measurements were performed on one European beech and on genetically identical mature individuals of English oak and two provenances of Norway spruce with the aim to study the light response of the emitted compounds. Our study shows that, despite the existence of differences in emission amounts, the relative contribution of the main emitted compounds was similar between the individuals of the same tree species. Compounds like isoprene showed a light dependency for all of the measured isoprene-emitting trees, whilst camphene showed a slight response from early spruce 2 and late spruce 2 going from darkness to $500 \mu \mathrm{mol} \mathrm{m}^{-2} \mathrm{~s}^{-1}$ but 
no significant response for the remaining trees. Apart from isoprene for English oak and sabinene for European beech, there was no clear light dependency of other emitted isoprenoids which could show a possible convergence in the response of these minor compounds to changes in light. For the provenances of spruce, some compounds like $\alpha$-pinene, 3carene and eucalyptol showed high light-dependent fractions for many of the individuals, which remained fairly stable with increasing light. This would possibly suggest that some MT compounds should be considered to be light-dependent in regard to emission models. As all measurements were performed on the lowest positioned branches of the tree, some trees showed indications of shade adaptation which could perhaps have inhibited the light response of certain compounds. The low sample size could also be responsible for the difficulty in finding statistically significant increases of emissions with light. However, the study does show a potential convergence of the light responses for compounds such as camphene for all the studied trees and monoterpene emission from English oak and European beech. This convergence needs to be studied further both for the mentioned compounds and for other tree species in order to fill in potential knowledge gaps, but we believe that this could possibly be of significance to improve emission modelling.

Data availability. The data set related to this study has been provided as a supplement. 


\section{Appendix A}

Table A1. The mean average actual emission ( \pm SD) of detected compounds at light levels (PAR) $0,500,1000$ and $1500 \mu \mathrm{molm} \mathrm{m}^{-2} \mathrm{~s}^{-1}$ and the number of samples taken from English oak (Quercus robur) in $\mu \mathrm{ggdw}{ }^{1} \mathrm{~h}^{-1}$. No data (n.d.) indicates that the compound was not detected in any sample for the measured light level on that particular tree.

\begin{tabular}{|c|c|c|c|c|c|c|c|c|}
\hline \multirow{2}{*}{$\begin{array}{l}\text { Tree } \\
\text { PAR }\end{array}$} & \multicolumn{4}{|c|}{ Oak $1(n=15)$} & \multicolumn{4}{|c|}{ Oak $2(n=17)$} \\
\hline & 0 & 500 & 1000 & 1500 & 0 & 500 & 1000 & 1500 \\
\hline ISO & n.d. & $5.08 \pm 2.32$ & $12.53 \pm 3.68$ & $16.31 \pm 2.91$ & 0.02 & $2.68 \pm 0.99$ & $6.53 \pm 2.0$ & $5.68 \pm 2.22$ \\
\hline Tricyclene & $<0.01$ & $<0.01 \pm<0.01$ & $0.01 \pm<0.01$ & $0.01 \pm<0.01$ & $<0.01$ & $<0.01$ & 0.01 & 0.01 \\
\hline$\alpha$-Pinene & $0.02 \pm<0.01$ & $0.01 \pm 0.01$ & $0.01 \pm<0.01$ & $0.01 \pm<0.01$ & $0.01 \pm<0.01$ & $0.01 \pm 0.01$ & $0.02 \pm 0.01$ & $0.03 \pm<0.01$ \\
\hline Camphene & $0.03 \pm 0.02$ & $0.01 \pm 0.01$ & $0.01 \pm 0.01$ & $0.02 \pm 0.01$ & $0.01 \pm<0.01$ & $0.04 \pm 0.02$ & $0.05 \pm 0.02$ & $0.04 \pm 0.03$ \\
\hline Sabinene & n.d. & n.d. & n.d. & n.d. & n.d. & n.d. & n.d. & n.d. \\
\hline$\beta$-Pinene & n.d. & n.d. & n.d. & n.d. & n.d. & n.d. & n.d. & n.d. \\
\hline 3-Carene & $0.02 \pm<0.01$ & $0.01 \pm<0.01$ & $0.01 \pm 0.01$ & $0.01 \pm<0.01$ & $0.01 \pm<0.01$ & $0.01 \pm 0.01$ & $0.01 \pm<0.01$ & $0.01 \pm 0.01$ \\
\hline$\alpha$-Terpinene & n.d. & n.d. & n.d. & n.d. & n.d. & n.d. & n.d. & n.d. \\
\hline Limonene & $0.08 \pm 0.04$ & $0.05 \pm 0.03$ & $0.05 \pm 0.03$ & $0.06 \pm 0.03$ & $0.03 \pm 0.01$ & $0.08 \pm 0.04$ & $0.09 \pm 0.02$ & $0.08 \pm 0.01$ \\
\hline Eucalyptol & $0.02 \pm<0.01$ & $0.01 \pm 0.01$ & $0.01 \pm<0.01$ & $0.01 \pm<0.01$ & $0.01 \pm<0.01$ & $0.02 \pm 0.01$ & $0.02 \pm<0.01$ & $0.03 \pm<0.01$ \\
\hline$\gamma$-Terpinene & n.d. & n.d. & n.d. & n.d. & n.d. & n.d. & n.d. & n.d. \\
\hline Linalool & n.d. & n.d. & n.d. & n.d. & n.d. & n.d. & n.d. & n.d. \\
\hline SQT & n.d. & n.d. & n.d. & n.d. & n.d. & n.d. & n.d. & n.d. \\
\hline Total & $0.16 \pm 0.08$ & $5.19 \pm 2.27$ & $12.62 \pm 3.65$ & $16.43 \pm 2.86$ & $0.05 \pm 0.03$ & $2.79 \pm 1.01$ & $6.68 \pm 1.95$ & $5.79 \pm 2.14$ \\
\hline
\end{tabular}




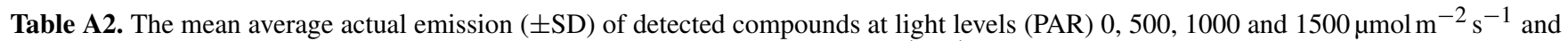
the number of samples taken from European beech (Fagus sylvatica) in $\mu \mathrm{ggdw}^{1} \mathrm{~h}^{-1}$. No data (n.d.) indicates that the compound was not detected in any sample for the measured light level on that particular tree.

\begin{tabular}{lrrrr}
\hline Tree & \multicolumn{4}{c}{ Beech $(n=21)$} \\
PAR & 0 & 500 & 1000 & 1500 \\
\hline ISO & n.d. & n.d. & n.d. & n.d. \\
Tricyclene & n.d. & $0.01 \pm 0.02$ & 0.01 & 0.01 \\
$\alpha$-Pinene & $0.04 \pm 0.03$ & $0.04 \pm 0.02$ & $0.06 \pm 0.06$ & $0.03 \pm 0.03$ \\
Camphene & $0.05 \pm 0.03$ & $0.06 \pm 0.03$ & $0.04 \pm 0.02$ & $0.03 \pm 0.02$ \\
Sabinene & n.d. & $0.52 \pm 0.78$ & $0.65 \pm 0.97$ & $0.75 \pm 1.05$ \\
$\beta$-Pinene & n.d. & n.d. & n.d. & n.d. \\
3-Carene & $0.04 \pm 0.03$ & $0.03 \pm 0.02$ & $0.03 \pm 0.03$ & $0.03 \pm 0.02$ \\
$\alpha$-Terpinene & n.d. & n.d. & n.d. & n.d. \\
Limonene & $0.09 \pm 0.05$ & $0.09 \pm 0.07$ & $0.06 \pm 0.05$ & $0.07 \pm 0.03$ \\
Eucalyptol & $0.03 \pm 0.01$ & $0.04 \pm 0.01$ & $0.03 \pm 0.01$ & $0.03 \pm 0.01$ \\
$\gamma$-Terpinene & n.d. & n.d. & n.d. & n.d. \\
Linalool & n.d. & n.d. & n.d. & n.d. \\
SQT & n.d. & n.d. & 0.02 & $0.04 \pm 0.06$ \\
\hline Total & $0.25 \pm 0.14$ & $0.79 \pm 0.76$ & $1.23 \pm 1.18$ & $0.99 \pm 1.05$ \\
\hline
\end{tabular}

Table A3. The mean average actual emission $\left( \pm\right.$ SD) of detected compounds at light levels (PAR) $0,500,1000$ and $1500 \mu m o l \mathrm{~m}^{-2} \mathrm{~s}^{-1}$ and the number of samples taken from the two provenances of spruce (Picea abies) in $\mu \mathrm{gdw}^{1} \mathrm{~h}^{-1}$. No data (n.d.) indicates that the compound was not detected in any sample for the measured light level on that particular tree.

\begin{tabular}{|c|c|c|c|c|c|c|c|c|}
\hline \multirow{2}{*}{$\begin{array}{l}\text { Tree } \\
\text { PAR }\end{array}$} & \multicolumn{4}{|c|}{ Early spruce $1(n=14)$} & \multicolumn{4}{|c|}{ Early spruce $2(n=13)$} \\
\hline & 0 & 500 & 1000 & 1500 & 0 & 500 & 1000 & 1500 \\
\hline ISO & n.d. & $0.18 \pm 0.03$ & $0.21 \pm 0.02$ & $0.25 \pm 0.03$ & n.d. & $0.23 \pm<0.01$ & 0.05 & $0.14 \pm 0.05$ \\
\hline Tricyclene & n.d. & n.d. & n.d. & $<0.01$ & $<0.01 \pm<0.01$ & n.d. & n.d. & n.d. \\
\hline$\alpha$-Pinene & $0.01 \pm 0.01$ & $0.03 \pm<0.01$ & $0.03 \pm 0.01$ & $0.03 \pm<0.01$ & $0.02 \pm<0.01$ & $0.02 \pm<0.01$ & $0.01 \pm<0.01$ & $0.03 \pm<0.01$ \\
\hline Camphene & $0.02 \pm 0.01$ & $0.02 \pm 0.01$ & $0.02 \pm 0.02$ & $0.02 \pm 0.01$ & $0.02 \pm<0.01$ & $<0.01 \pm<0.01$ & $0.01 \pm 0.01$ & $<0.01 \pm<0.01$ \\
\hline Sabinene & n.d. & n.d. & n.d. & n.d. & n.d. & n.d. & n.d. & n.d. \\
\hline$\beta$-Pinene & n.d. & $0.02 \pm 0.01$ & $0.01 \pm 0.01$ & $0.02 \pm<0.01$ & n.d. & n.d. & n.d. & $0.02 \pm<0.01$ \\
\hline 3-Carene & $<0.01 \pm<0.01$ & $0.06 \pm 0.03$ & $0.04 \pm 0.02$ & $0.01 \pm<0.01$ & $0.01 \pm<0.01$ & $0.01 \pm<0.01$ & $0.01 \pm<0.01$ & $0.01 \pm<0.01$ \\
\hline$\alpha$-Terpinene & n.d. & n.d. & n.d. & n.d. & n.d. & n.d. & n.d. & n.d. \\
\hline Limonene & $0.01 \pm 0.01$ & $0.08 \pm 0.01$ & $0.06 \pm 0.01$ & $0.05 \pm<0.01$ & $0.04 \pm 0.02$ & $0.07 \pm 0.01$ & 0.01 & $0.04 \pm<0.01$ \\
\hline Eucalyptol & $0.01 \pm<0.01$ & $0.04 \pm 0.01$ & $0.05 \pm 0.01$ & $0.06 \pm<0.01$ & $0.01 \pm 0.01$ & $0.04 \pm<0.01$ & $0.02 \pm 0.02$ & $0.05 \pm<0.01$ \\
\hline$\gamma$-Terpinene & n.d. & n.d. & n.d. & n.d. & n.d. & n.d. & n.d. & n.d. \\
\hline Linalool & n.d. & n.d. & n.d. & $0.14 \pm 0.01$ & n.d. & n.d. & n.d. & n.d. \\
\hline SQT & n.d. & $0.10 \pm 0.07$ & $0.16 \pm 0.08$ & n.d. & n.d. & n.d. & n.d. & n.d. \\
\hline Total & $0.05 \pm 0.03$ & $0.54 \pm 0.04$ & $0.58 \pm 0.09$ & $0.60 \pm 0.05$ & $0.10 \pm 0.04$ & $0.37 \pm 0.02$ & $0.12 \pm 0.13$ & $0.29 \pm 0.05$ \\
\hline Tree & \multicolumn{4}{|c|}{ Late spruce $1(n=13)$} & \multicolumn{4}{|c|}{ Late spruce $2(n=18)$} \\
\hline PAR & 0 & 500 & 1000 & 1500 & 0 & 500 & 1000 & 1500 \\
\hline ISO & n.d. & $0.31 \pm 0.13$ & $1.26 \pm 0.49$ & $0.54 \pm 0.04$ & n.d. & $0.30 \pm 0.16$ & $0.45 \pm 0.06$ & $0.33 \pm 0.03$ \\
\hline Tricyclene & n.d. & $<0.01$ & $0.01 \pm 0.01$ & $0.01 \pm<0.01$ & n.d. & n.d. & n.d. & n.d. \\
\hline$\alpha$-Pinene & $<0.01$ & $0.09 \pm 0.09$ & $0.29 \pm 0.26$ & $0.23 \pm 0.01$ & $0.02 \pm 0.01$ & $0.14 \pm 0.07$ & $0.20 \pm 0.01$ & $0.02 \pm 0.04$ \\
\hline Camphene & $0.03 \pm 0.02$ & $0.02 \pm 0.01$ & $0.21 \pm 0.27$ & $0.01 \pm<0.01$ & $0.03 \pm 0.02$ & $<0.01 \pm<0.01$ & $<0.01 \pm<0.01$ & $<0.01 \pm<0.01$ \\
\hline Sabinene & n.d. & n.d. & n.d. & n.d. & n.d. & n.d. & n.d. & n.d. \\
\hline$\beta$-Pinene & n.d. & 0.01 & $0.07 \pm 0.03$ & $0.03 \pm<0.01$ & n.d. & $0.02 \pm 0.02$ & $0.03 \pm<0.01$ & $0.03 \pm 0.01$ \\
\hline 3-Carene & n.d. & 0.01 & $0.02 \pm 0.01$ & $0.01 \pm<0.01$ & $0.04 \pm 0.01$ & $0.05 \pm 0.04$ & $0.06 \pm<0.01$ & $0.05 \pm 0.01$ \\
\hline$\alpha$-Terpinene & n.d. & 0.01 & $0.04 \pm 0.02$ & $0.02 \pm<0.01$ & n.d. & n.d. & n.d. & n.d. \\
\hline Limonene & $0.01 \pm 0.01$ & $0.02 \pm 0.03$ & $0.05 \pm 0.05$ & $0.04 \pm<0.01$ & $0.04 \pm 0.02$ & $0.06 \pm 0.05$ & $0.06 \pm 0.01$ & $0.05 \pm 0.01$ \\
\hline Eucalyptol & $<0.01$ & $0.01 \pm 0.01$ & $0.10 \pm 0.05$ & $0.03 \pm<0.01$ & $0.01 \pm 0.01$ & $0.02 \pm 0.02$ & $0.03 \pm<0.01$ & $0.04 \pm<0.01$ \\
\hline$\gamma$-Terpinene & n.d. & n.d. & $0.10 \pm 0.06$ & $0.03 \pm<0.01$ & n.d. & n.d. & $0.02 \pm 0.02$ & $0.02 \pm 0.02$ \\
\hline Linalool & n.d. & n.d. & n.d. & n.d. & n.d. & n.d. & n.d. & n.d. \\
\hline SQT & n.d. & n.d. & n.d. & n.d. & n.d. & n.d. & n.d. & n.d. \\
\hline Total & $0.04 \pm 0.03$ & $0.49 \pm 0.30$ & $2.16 \pm 0.84$ & $0.93 \pm 0.04$ & $0.25 \pm 0.12$ & $1.17 \pm 0.70$ & $1.69 \pm 0.12$ & $1.41 \pm 0.08$ \\
\hline
\end{tabular}




\section{The Supplement related to this article is available online at https://doi.org/10.5194/bg-14-4045-2017-supplement.}

Competing interests. The authors declare that they have no conflict of interest.

Acknowledgements. The authors would like to thank Vetenskapsrådet (VR 621-2011-3190) for partly funding the project. We are grateful to Anders K. Nørgaard and the rest of the staff at the experimental farms in Taastrup, University of Copenhagen, for their support in the field and for providing facilities. We are also grateful to Gosha Sylvester at the University of Copenhagen for performing BVOC sample analysis. Magnus Kramshøj, Frida Lindwall, Jing Tang, Michelle Schollert Reneerkens and Janne Rinne provided valuable comments on the manuscript. The study was performed within the framework of LUCCI, which is a research centre at Lund University for studies of carbon cycles and climate interaction.

Edited by: Xinming Wang

Reviewed by: Jianhui Bai and one anonymous referee

\section{References}

Atkinson, R.: Atmospheric chemistry of VOCs and $\mathrm{NO}_{x}$, Atmos. Environ., 34, 2063-2101, https://doi.org/10.1016/S13522310(99)00460-4, 2000.

Atkinson, R. and Arey, J.: Gas-phase tropospheric chemistry of biogenic volatile organic compounds: a review, Atmos. Environ., 37, 197-219, https://doi.org/10.1016/S1352-2310(03)00391-1, 2003.

Bäck, J., Hari, P., Hakola, H., Juurola, E., and Kulmala, M.: Dynamics of monoterpene emissions in Pinus sylvestris during early spring, Boreal Environ. Res., 10, 409-424, 2005.

Bäck, J., Aalto, J., Henriksson, M., Hakola, H., He, Q., and Boy, M.: Chemodiversity of a Scots pine stand and implications for terpene air concentrations, Biogeosciences, 9, 689-702, https://doi.org/10.5194/bg-9-689-2012, 2012.

Chmielewski, F.-M., Heider, S., and Moryson, S.: International Phenological Observation Networks: concept of IPG and GPM, in: Phenology: an Integrative Environmental Science, edited by: Schwartz, M. D., Springer Science and Business Media B. V., Dordrecht, 137-153, https://doi.org/10.1007/978-94-007-6925$0 \_8,2013$.

Claeys, M., Graham, B., Vas, G., Wang, W., Vermeylen, R., Pashynska, V., Cafmeyer, J., Guyon, P., Andreae, M. O., Artaxo, P., and Maenhaut, W.: Formation of secondary organic aerosols through photooxidation of isoprene, Science, 303, 1173-1176, https://doi.org/10.1126/science.1092805, 2004.

Danish Meteorological Institute: available at: http://www.dmi.dk/ en/, last access: 1 September 2016.

Dindorf, T., Kuhn, U., Ganzeveld, L., Schebeske, G., Ciccioli, P., Holzke, C., Köble, R., Seufert, G., and Kesselmeier, J.: Significant light and temperature dependent monoterpene emissions from European beech (Fagus sylvatica L.) and their potential impact on the European volatile organic compound budget, J. Geophys. Res.-Atmos., 111, D16305, https://doi.org/10.1029/2005JD006751, 2006.

Dudareva, N., Negre, F., Nagegowda, D. A., and Orlova, I.: Plant Volatiles: Recent Advances and $\mathrm{Fu}-$ ture Perspectives, Crit. Rev. Plant Sci., 25, 417-440, https://doi.org/10.1080/07352680600899973, 2006.

Ehn, M., Thornton, J. A., Kleist, E., Sipilä, M., Junninen, H., Pullinen, I., Springer, M., Rubach, F., Tillmann, R., Lee, B., Lopez-Hilfiker, F., Andres, S., Acir, I.-H., Rissanen, M., Jokinen, T., Schobesberger, S., Kangasluoma, J., Kontkanen, J., Nieminen, T., Kurtén, T., Nielsen, L. B., Jørgensen, S., Kjaergaard, H. G., Canagaratna, M., Dal Maso, M., Berndt, T., Petäjä, T., Wahner, A., Kerminen, V.-M., Kulmala, M., Worsnop, D. R., Wildt, J., and Mentel, T. F.: A large source of low-volatility secondary organic aerosol, Nature, 506, 476-479, https://doi.org/10.1038/nature13032, 2014.

Fuentes, J. D., Wang, D., Neumann, H. H., Gillespie, T. J., den Hartog, G., and Dann, T. F.: Ambient biogenic hydrocarbons and isoprene emissions from a mixed deciduous forest, J. Atmos. Chem., 25, 67-95, 1996.

Ghirardo, A., Koch, K., Taipale, R., Zimmer, I., Schnitzler, J. - P., and Rinne, J.: Determination of de novo and pool emissions of terpenes from four common boreal/alpine trees by ${ }^{13} \mathrm{CO}_{2}$ labelling and PTR-MS analysis, Plant Cell Environ., 33, 781-792, https://doi.org/10.1111/j.1365-3040.2009.02104.x, 2010.

Goldstein, A. H. and Galbally, I. E.: Known and unexplored organic constituents in the earth's atmosphere, Environ. Sci. Technol., 41, 1514-1521, 2007.

Grabmer, W., Kreuzwieser, J., Wisthaler, A., Cojocariu, C., Graus, M., Rennenberg, H., Steigner, D., Steinbrecher, R., and Hansel, A.: VOC emissions from Norway spruce (Picea abies L. [Karst]) twigs in the field - Results of a dynamic enclosure study, Atmos. Environ., 40, 128-137, https://doi.org/10.1016/j.atmosenv.2006.03.043, 2006.

Guenther, A., Hewitt, C. N., Erickson, D., Fall, R., Geron, C., Graedel, T., Harley, P., Klinger, L., Lerdau, M., McKay, W. A., Pierce, T., Scholes, B., Steinbrecher, R., Tallamraju, R., Taylor, J., and Zimmerman, P.: A global model of natural volatile organic compound emissions, J. Geophys. Res.-Atmos., 100, 8873-8892, 1995.

Guenther, A. B., Jiang, X., Heald, C. L., Sakulyanontvittaya, T., Duhl, T., Emmons, L. K., and Wang, X.: The Model of Emissions of Gases and Aerosols from Nature version 2.1 (MEGAN2.1): an extended and updated framework for modeling biogenic emissions, Geosci. Model Dev., 5, 1471-1492, https://doi.org/10.5194/gmd-5-1471-2012, 2012.

Holopainen, J. K. and Gershenzon, J.: Multiple stress factors and the emission of plant VOCs, Trends Plant Sci., 15, 176-184, https://doi.org/10.1016/j.tplants.2010.01.006, 2011.

Holzke, C., Dindorf, T., Kesselmeier, J., Kuhn, U., and Koppmann, R.: Terpene emissions from European beech ( $\mathrm{Fa}$ gus sylvatica L.): pattern and emission behaviour over two vegetation periods, J. Atmos. Chem., 55, 81-102, https://doi.org/10.1007/s10874-006-9027-9, 2006.

Isidorov, V. A., Zenkevich, I. G., and Ioffe, B. V.: Volatile organic compounds in the atmosphere of forests, Atmos. Environ., 19, $1-8,1985$. 
Kesselmeier, J. and Staudt, M.: Biogenic Volatile Organic Compounds (VOC): an overview on emission, physiology and ecology, Atmos. Chem., 33, 23-88, 1999.

Laffineur, Q., Aubinet, M., Schoon, N., Amelynck, C., Müller, J.F., Dewulf, J., Van Langenhove, H., Steppe, K., Šimpraga, M., and Heinesch, B.: Isoprene and monoterpene emissions from a mixed temperate forest, Atmos. Environ., 45, 3157-3168, https://doi.org/10.1016/j.atmosenv.2011.02.054, 2011.

Laothawornkitkul, J., Taylor, J. E., Paul, N. D., and Hewitt, C. N.: Biogenic volatile organic compounds in the Earth system, New Phytol., 183, 27-51, https://doi.org/10.1111/j.14698137.2009.02859.x, 2009.

Le Thiec, D., Dixon, M., and Garrec, J. P.: The effects of slightly elevated ozone concentrations and mild drought stress on the physiology and growth of Norway spruce, Picea abies (L.) Karst., and beech, Fagus sylvatica L., in open-top chambers, New Phytol., 128, 671-678, 1994.

Lee, A., Goldstein, A. H., Kroll, J. H., Ng, N. L., Varutbangkul, V., Flagan, R. C., and Seinfeld, J. H.: Gas-phase products and secondary aerosol yields from the photooxidation of 16 different terpenes, J. Geophys. Res., 111, D17305, https://doi.org/10.1029/2006JD007050, 2006.

Lehning, A., Zimmer, I., Steinbrecher, R., Brüggemann, N., and Schnitzler, J.-P.: Isoprene synthase activity and its relation to isoprene emission in Quercus robur L. leaves, Plant Cell Environ., 22, 495-504, 1999.

Lerdau, M., Litvak, M., Palmer, P., and Monson, R.: Controls over monoterpene emissions from boreal forest conifers, Tree Physiol., 17, 563-569, 1997.

Lichtenthaler, H. K.: Biosynthesis, accumulation and emission of carotenoids, $\alpha$-tocopherol, plastoquinone, and isoprene in leaves under high photosynthetic irradiance, Photosynth. Res., 92, 163179, https://doi.org/10.1007/s11120-007-9204-y, 2007.

Loreto, F., Ciccioli, P., Brancaleoni, E., Frattoni, M., and Delfine, S.: Incomplete ${ }^{13} \mathrm{C}$ labelling of $\alpha$-pinene content of Quercus ilex leaves and appearance of unlabelled C in $\alpha$-pinene, Plant Cell Environ., 23, 229-234, 2000.

van Meeningen, Y., Schurgers, G., Rinnan, R., and Holst, T.: BVOC emissions from English oak (Quercus robur) and European beech (Fagus sylvatica) along a latitudinal gradient, Biogeosciences, 13, 6067-6080, https://doi.org/10.5194/bg-13-6067-2016, 2016.

Morecroft, M. D. and Roberts, J. M.: Photosynthesis and stomatal conductance of mature canopy oak (Quercus robur) and sycamore (Acer pseudoplatanus) trees throughout the growing season, Funct. Ecol., 13, 332-342, 1999.

Moukhtar, S., Bessagnet, B., Rouil, L., and Simon, V.: Monoterpene emissions from Beech (Fagus sylvatica) in a French forest and impact on secondary pollutants formation at regional scale, Atmos. Environ., 39, 3535-3547, https://doi.org/10.1016/j.atmosenv.2005.02.031, 2005.

Moukhtar, S., Couret, C., Rouil, L., and Simon, V.: Biogenic volatile organic compounds (BVOCs) emissions from Abies alba in a French forest, Sci. Total Environ., 354, 232-245, https://doi.org/10.1016/j.scitotenv.2005.01.044, 2006.

Niinemets, Ü. and Reichstein, M.: Controls on the emission of plant volatiles through stomata: differential sensitivity of emission rates to stomatal closure explained, J. Geophys. Res.-Atmos., 108, D7, https://doi.org/10.1029/2002JD002620, 2003.
Niinemets, Ü., Loreto, F., and Reichstein, M.: Physiological and physicochemical controls on foliar volatile organic compound emissions, Trends Plant Sci., 9, 180-186, https://doi.org/10.1016/j.tplants.2004.02.006, 2004.

Ortega, J. and Helmig, D.: Approaches for quantifying reactive and low-volatility biogenic organic compound emissions by vegetation enclosure techniques - Part A, Chemosphere, 72, 343-364, 2008.

Paasonen, P., Asmi, A., Petäjä, T., Kajos, M. K., Äijälä, M., Junninen, H., Holst, T., Abbatt, J. P. D., Arneth, A., Birmili, W., van der Gon, H. D., Hamed, A., Hoffer, A., Laakso, L., Laaksonen, A., Leaitch, W. R., Plass-Dülmer, C., Pryor, S. C., Räisänen, P., Swietlicki, E., Wiedensohler, A., Worsnop, D. R., Kerminen, V.-M., and Kulmala, M.: Warming-induced increase in aerosol number concentration likely to moderate climate change, Nat. Geosci., 6, 438-442, https://doi.org/10.1038/ngeo1800, 2013.

Peñuelas, J. and Staudt, M.: BVOCs and global change, Trends Plant Sci., 15, 133-144, https://doi.org/10.1016/j.tplants.2009.12.005, 2010.

Persson, Y., Schurgers, G., Ekberg, A., and Holst, T.: Effects of intra-genotypic variation, variance with height and time of season on BVOC emissions, Meteorol. Z., 25, 377-388, https://doi.org/10.1127/metz/2016/0674, 2016.

Pokorska, O., Dewulf, J., Amelynck, C., Schoon, N., Joó, É., Šimpraga, M., Bloemen, J., Steppe, K., and Van Langenhove, H.: Emissions of biogenic volatile organic compounds from Fraxinus excelsior and Quercus robur under ambient conditions in Flanders (Belgium), Int. J. Environ. An. Ch., 92, 1729-1741, https://doi.org/10.1080/03067319.2011.581757, 2012.

Roberntz, P. and Stockfors, J. A. N.: Effects of elevated $\mathrm{CO}_{2}$ concentration and nutrition on net photosynthesis, stomatal conductance and needle respiration of field-grown Norway spruce trees, Tree Physiol., 18, 233-241, 1998.

Rstudio Team: RStudio: Integrated Development for R, Boston, MA, available at: http://www.rstudio.com (last access: 1 July 2015), 2015.

Scartazza, A., Di Baccio, D., Bertolotto, P., Gavrichkova, O., and Matteucci, G.: Investigating the European beech (Fagus sylvatica L.) leaf characteristics along the vertical canopy profile: leaf structure, photosynthetic capacity, light energy dissipation and photoprotection mechanisms, Tree Physiol., 31, 1-17, https://doi.org/10.1093/treephys/tpw038, 2016.

Schurgers, G., Arneth, A., and Hickler, T.: Effect of climate-driven changes in species composition on regional emission capacities of biogenic compounds, J. Geophys. Res.-Atmos., 116, D22304, https://doi.org/10.1029/2011JD016278, 2011.

Shao, M., Czapiewski, K. V., Heiden, A. C., Kobel, K., Komeda, M., Koppman, R., and Wildt, J.: Volatile organic compound emissions from Scots pine: mechanisms and description by algorithms, J. Geophys. Res.-Atmos., 106, 20483-20491, 2001.

Skjøth, C. A., Geels, C., Hvidberg, M., Hertel, O., Brandt, J., Frohn, L. M., Hansen, K. M., Hedegård, G. B., Christensen, J. H., and Moseholm, L.: An inventory of tree species in Europe - an essential data input for air pollution modelling, Ecol. Model., 217, 292-304, https://doi.org/10.1016/j.ecolmodel.2008.06.023, 2008.

Song, W., Staudt, M., Bourgeois, I., and Williams, J.: Laboratory and field measurements of enantiomeric monoterpene emis- 
sions as a function of chemotype, light and temperature, Biogeosciences, 11, 1435-1447, https://doi.org/10.5194/bg-11-14352014, 2014.

Špunda, V., Kalina, J., Urban, O., Luis, V. C., Sibisse, I., Puértolas, J., Šprtová, M., and Marek, M. V.: Diurnal dynamics of photosynthetic parameters of Norway spruce trees cultivated under ambient and elevated $\mathrm{CO}_{2}$ : the reasons of midday depression in $\mathrm{CO}_{2}$ assimilation, Plant Sci., 168, 1371-1381, https://doi.org/10.1016/j.plantsci.2005.02.002, 2005.

Staudt, M. and Bertin, N.: Light and temperature dependence of the emission of cyclic and acyclic monoterpenes from holm oak (Quercus ilex L.) leaves, Plant Cell Environ., 21, 385-395, 1998.

Staudt, M. and Lhoutellier, L.: Monoterpene and sesquiterpene emissions from Quercus coccifera exhibit interacting responses to light and temperature, Biogeosciences, 8, 2757-2771, https://doi.org/10.5194/bg-8-2757-2011, 2011.

Staudt, M. and Seufert, G.: Light-dependent emission of monoterpenes by Holm oak (Quercus ilex L.), Naturwissenschaften, 82, 89-92, 1995.

Staudt, M., Mandl, N., Joffre, R., and Rambal, S.: Intraspecific variability of monoterpene composition emitted by Quercus ilex leaves, Can. J. Forest Res., 31, 174-180, https://doi.org/10.1139/x00-153, 2001.

Taipale, R., Kajos, M. K., Patokoski, J., Rantala, P., Ruuskanen, T. M., and Rinne, J.: Role of de novo biosynthesis in ecosystem scale monoterpene emissions from a boreal Scots pine forest, Biogeosciences, 8, 2247-2255, https://doi.org/10.5194/bg-82247-2011, 2011.
Tarvainen, V., Hakola, H., Hellén, H., Bäck, J., Hari, P., and Kulmala, M.: Temperature and light dependence of the VOC emissions of Scots pine, Atmos. Chem. Phys., 5, 989-998, https://doi.org/10.5194/acp-5-989-2005, 2005.

Tingey, D. T., Manning, M., Grothaus, L. C., and Burns, W. F.: Influence of light and temperature on monoterpene emission rates from Slash pine, Plant Physiol., 65, 797-801, https://doi.org/10.1104/pp.65.5.797, 1980.

Tingey, D. T., Evans, R., and Gumpertz, M.: Effects of environmental conditions on isoprene emission from live oak, Planta, 152, 565-570, 1981.

Tollsten, L. and Müller, P. M.: Volatile organic compounds emitted from beech leaves, Phytochemistry, 43, 759-762, 1996.

Valladares, F., Manuel, J., Aranda, I., Balaguer, L., and Dizengremel, P.: The greater seedling high-light tolerance of Quercus robur over Fagus sylvatica is linked to a greater physiological plasticity, Trees, 16, 395-403, https://doi.org/10.1007/s00468002-0184-4, 2002.

von Caemmerer, S. and Farquhar, G. D.: Some relationships between the biochemistry of photosynthesis and the gas exchange of leaves, Planta, 153, 376-387, 1981.

Warren, C. R., Matyssek, R., and Tausz, M.: Internal conductance to $\mathrm{CO}_{2}$ transfer of adult Fagus sylvatica: variation between sun and shade leaves and due to freeair ozone fumigation, Environ. Exp. Bot., 59, 130-138, https://doi.org/10.1016/j.envexpbot.2005.11.004, 2007. 